УДК 947.0

https://doi.org/10.24852/2587-6112.2021.3.114.123

\title{
МУДРОСТЬ В ПРЕДСТАВЛЕНИЯХ ТЮРКО-ТАТАР 1 (НЕКОТОРЫЕ НАБЛЮДЕНИЯ)
}

\author{
С2021 г. Г.М. Давлетшин
}

Общество древних тюрков с кочевым укладом жизни требовало всегда смелости, смекалки, героизма. Слава мужчины определялась тем, сколько врагов он убил. Но все же в древнетюркских рунических надписях на первое место ставится ум и только потом сила. Тенгре дарит каганам разум, только после этого он их ставит править над тюркским народом. В данной статье на основе комплекса источников рассматриваются представления тюрко-татар - предков татарского народа о мудрости в ее различных проявлениях. Эти представления, сформировавшиеся в древности, сохранив свою суть, дошли до поздних времен и играли важную роль в традиционной культуре татар. Материалы статьи могут быть полезными для более глубокого понимания, осмысления жизни, духовного мира тюрко-татар.

Ключевые слова: история, мудрость, разум, каган, знание, филин, тюрк.

\section{WISDOM IN THE PERCEPTION OF THE TÜRCO-TATARS (OBSERVATIONS)}

\section{G.M. Davletshin}

The society of the ancient Turks with a nomadic way of life always required courage, ingenuity, and heroism. The glory of man was determined by how many enemies he had killed. But still, in the ancient Turkic runic inscriptions, the mind is in the first place, and the power is in the second. Tengre gives the kagans reason, and only after that he lets them rule over the Turkic people. This paper, based on a set of sources, addresses the ideas of the Turkic-Tatar ancestors of the Tatar people about wisdom in its various manifestations. These ideas, which formed in ancient times, having preserved their essence, reached later times and played an important role in the traditional culture of the Tatars. The materials of the paper can be useful for a deeper understanding and comprehension of the life and spiritual world of the Turkic-Tatars.

Keywords: history, wisdom, reason, kagan, knowledge, owl, Turk.

Мудрость, ум означают и философские, психологические и религиозные понятия. Они - своеобразный измеритель степени познания окружающего мира, умение применять глубокие знания. Мудрость в религиозном понимании - это самая высокая степень познания окружающего мира, которой обладают в совершенстве только боги, а люди способны постигнуть её лишь в той или иной мере. У разных народов бытовали специальные боги мудрости. В более древний период олицетворяли его различные животные-тотемы. В классовых обществах в первую очередь этим свойством обладали правители, их приближенные, высшие религиозные деятели, святые. Мудрость неразрывно связана с умом, грамотностью, образованием, просвещением. Эти общечеловеческие черты были характерны и тюрко-татарам. Но имели свои особенности, исходящие особой историей, общества, духовного мира и т.д.

Материалы, дошедшие до нас в письменных источниках, скудны, противоречивы и содержат субъективную трактовку. Поэтому при изучении данной проблемы нам приходит- ся обращаться к археологическим памятникам той эпохи, также к произведениям устного народного творчества, языковым и этнографическим материалам. Однако эти источники, взятые в отдельности, не могут определить все многообразие проявления мудрости тюрко-татар. Так, археологические памятники сами по себе лишь отдельные застывшие элементы этой культуры. Ключом к разгадке являются этнографические, языковые материалы. Но данные современного фольклора, этнографии, языка, отдельно взятые, не могут служить непосредственным материалом для изучения духовной жизни населения, отдаленного от нас столетиями. В них запечатлены особенности разных времен. Задача состоит в том, чтобы выявить древние пласты этих памятников, найти их исторические корни. Это возможно сделать лишь при сопоставлении фольклорных и лингвистических данных с археологическими материалами.

\section{Мудрость и история}

Древние тюрки возводили в культ свое прошлое, историю и стремились остаться верными идеалам мудрых предков. Яркий 
пример идеализации прошлого народа сохранился в орхоно-енисейских рунических письменах. О праотцах — каганах Бумыне и Истеми - говорится сразу же после упоминания о сотворении мира. По глубокому убеждению тюрков, чем древнее описываемые события и предки - их участники, тем более они мудры и легендарны. При Бумын и Истеми совершались славные дела. Они самые первые древние каганы тюрок, значит, и самые могущественные, мудрые, приведшие тюрок к славным победам герои. Они близки к мифическим «культурным героям». Первые каганы образовали для тюрок государство, создали законы их бытия. Современное поколение правителей призывали брать пример с них. Над погребениями таких предков сооружались величественные храмы. Среди них особо выделяются надгробные сооружения, поставленных на берегу реки Орхона в честь хана и военачальника тюрок Кюль-тегина (памятник Хушо-Цайдам II) (732) и кагана Могиляна (Бильге) (734) (памятник Хушо-Цайдам I). Кроме них, выделяется памятник близ УланБатора (Цаган-Обо I), поставленный в 720 годах в честь «мудрого Тонйукука» - военачальника, советника Ильтереса (692), каганов Капагана (716) и Могиляна, соправителя (в скобках годы смерти) (Войтов, 1996, с. 31, 32; Гумилев, 1993, с. 328-329). Эти памятники посвящены мудрым предкам.

Культ истории, предков прослеживается и особым положением в тюрко-татарских обществах пожилых людей, накопившие жизненный опыт и мудрость. Например, Ахмед ибн Фадлан так пишет об обычае в Волжской Булгарии: «...если у сына (какого-либо) человека родится ребенок, то его берет (к себе) его дед прежде его отца, говорит: «я имею больше прав, чем его отец, на его воспитание, пока он не сделается (взрослым) мужем» (Ковалевский, 1956, с. 137). Этот древний обычай распространен у многих народов. Мальчик находился до совершеннолетия у деда и там приобретал навыки, мудрость жизни.

В Казанском ханстве, как и в других татарских позднезолотоордынских государствах, так же, как и древних булгарах, дети ханов, высших чиновников воспитывались умудренными жизненным опытом старцами, которые были окружены почетом и большим уважением. Их величали «молочными отцами (сөт аталары), аталыками». Это явление называлось аталычеством. Даже один из ворот Казанского Кремля назывался Аталыкским. Например, как пишет Шериф Тархани в одной из ворот Кремля стоял со своим войском «Барболсун Аталык, который, словно со знаменем Дара, и такой же ловкий, как Искандер, образец Рустема и похожий на Бахрама» (Шерефи, 1995, с. 90).

Ho, с другой стороны, правитель преклонного возраста, когда он уже ослаб телом, душой и разумом был крайне нежелателен для управления государством, особенно для кочевого общества тюрко-татар. Ослабление ума правителя могло привести к различным бедствиям для народа и государства. Посадив его на коня, «стягивали шелковой тканью горло и, быстро ослабив петлю, спрашивали, сколько лет он желает быть ханом» (Гумилев, 1993, с. 40). Этот древний ритуал продолжал существовать и в Хазарии - наследнице Тюркского каганата. Ибн Фадлан пишет об ограничении правления хазарского кагана сороколетнем сроком (Ковалевский, 1956, с. 147).

\section{Мудрость и власть, святость}

Мудрость исходит из самого Тенгре, она божий дар. Тенгре дарит каганам разум, только после этого их ставит править над тюркским народом. Для правления «сынами человеческими» ставятся каганы Бумын и Истеми (Малов, 1951, с. 36).

Таким образом, мудрость считалась неотъемлемой чертой каганов. Эпитет «мудрый» даже становится одним из имен, возможно даже одним из титулов каганов и их советников. Среди них Билге (Мудрый) каган и его советник Тонйукук. Они всегда подчеркивали свою мудрость (например, в древних надписях часто видим выражение «Я мудрый Тонйукук»). Понятие мудрости в древнетюркском обществе было шире, чем по нашим представлениям. Оно имело и самое реальное практическое значение в жизни тюркского общества. Например, Тонйукук был не просто «мудрым», но и талантливым полководцем. Мудрость резко отличался от формального «мудрствования».

Однако не любая грамотность, чужой опыт, мудрость была приняты тюрко-татарскими обществами. Особенно проблемными были отношения хуннов/гуннов, древних тюрок с соседним Китаем. "Прелещая сладкой речью и роскошными драгоценностями, они столь сильно привлекали к себе далеко жившие народы. Т.е., поселяясь вплотную, затем усвоили себе там дурное мудрование", говорится в древнетюркских рунах (Малов, 1951, с. 34).

В этом есть своя причина. Краеугольным камнем официальной идеологии Великого 
Тюркского каганата было беречь государство и тюркский народ (турк будун) как зеницу ока, причем сохранить этот народ не каким угодно, а именно тюркским, не смешанным с другими народами, культурами. С этой точки зрения именно многочисленный китайский народ и его древнейшая всемирного значения культура, глубокие философские учения представляли серьезную угрозу. Тюрки понимали, что это вполне реально, быть поглощенными китайцами и раствориться в их среде и в их «дурном мудрствовании», чужом для древнетюркского общества. Один из основных идеологических принципов историка, кагана Восточно-Тюркского каганата Йоллыг тегина Ижань хана (734-739) был: «Держись от Китая подальше. Не отходи от Китая слишком далеко» (Гумилев, 1993, с. 337).

С образованием централизованного государства и принятием ислама ореол святости, мудрости перешел к царям, их приближенным, религиозным служителям, военачальникам.

Сосредоточение в одном лице политической и духовной власти не ново в истории древних тюрок и хазаро-болгар. По представлению древних тюрок, власть ханам была дарована самим верховным божеством - Тенгре. Таким был хазарский каган (где каган представлял небесную власть), главными жрецами были и ханы Первого Болгарского царства на Дунае. Стало быть, основная идея все та же: властью наделяются с небес по воле всевышнего, поэтому сопротивление этому большой грех, святотатство. Здесь очень тонкая официальная идеология. Сами правители также стремятся быть похожими на небожителей. Так, царь Алмыш, показывая свое величие и святость, заявляет, что верховная власть ему была дарована Аллахом (Ковалевский, 1956, с. 139).

\section{Мудрость и просвещение}

Достичь мудрости возможно было не только естественным путем, божественным предопределением, но и приобретением грамотности, образования, просвещения. Своего рода высшей ступенью образования считалось получение знаний в соседнем Китае. Учились в Китае Йоллыг тегин и командующий войском, советник ханов мудрый Тонйукук. Тонйукук (по-тюркски Таңюкук или Төнюкук) - самый древний, известный нам мудрец тюрок, государственный советник каганов Ильтереса, Богю, Бильге, Капаган, военачальник. Мудрый Тонйукук был не только мудрым, но, получив образование в Табгаче (Китае), стал ученым по различным отраслям науки. Например, хорошо знал географические особенности Табгача, изучал по карте, документальным источникам места водных, горных переправ и т.д. (Кляшторный, 1964, с. 28).

Таким образом, свое славное имя Тонйукук заслужил после получения образования, воспитания в Китае, когда «созрел» («стал мудрым») и занимал высокие должности в государстве тюрков.

Такое обучение представителей кочевников (для китайцев - «варваров») сильно озаботили китайских идеологов, так как кочевники при военных столкновениях смогли использовать эти знания в своих целях. Со своей стороны, и древнетюркское общество сближение с Китаем восприняло неоднозначно: в древнетюркских рунических надписях осуждается то, что тюрки восприняли и некоторые плохие, дурные привычки китайцев, например, употребление алкоголя.

Грамотность, знания были в большом почете в тюркской элите. Она считала образованность своим высоким достоинством. В этом отношении из турфанских (древнеуйгурских) текстов привлекает внимание следующая песня:

«Билиг билиң, йа бәгим!

Билиг сәнга әш булур,

билиг билгән ол әркә

бир күн тавлат туш болур.

(Узнай знание, о, бек мой!

Знание тебе к лицу;

тому мужчине со знанием

однажды наступит счастье) (Татар педагогик фикере антологиясе, 2014, с. 31).

И в других рукописях, найденных в пещере Дуньхуан, есть великолепные мысли. Например, одна из них так звучит: «Туймаг билиг тутунучсуз йарук йула тег (знание, постижения, познание - как неугасаемый, светлый факел) (Татар педагогик фикере антологиясе, 2014, c. 32).

Образованность, стремление к образованию было объявлено святой обязанностью каждого мусульманина.

В известном прозаическом произведении «Нахдж ал-Фарадис», созданном в 1358 году булгарским автором Махмудом бине Гали шейх ас-Сараи ал-Булгари, проводится мысль о том, что ученья, знания в своей основе восходят к Аллаху. Вот как отвечает ученый казый (судья) на вопрос Хатама Асама в рассказе «Хатам Асам»: «Знания (мудрость) исходят из Вселенной. Вселенная получила их от тех, кто знал и видел тех, кто знал и видел пророка Мухаммада, а пророк Мухаммад полу- 
чил знания от Жабраила, а Жабраил получил эти знания от самого Всевышнего (Мәхмүд әл-Болгари, 2002, с. 33-234).

Во времена М. Кашгари, вообще, знание считалось символом счастья ("Кут белгүси билиг») (Кошгари, 1960-1963; Мәхмүтов, 2002, с. 103).

Могущественный хан Крыма Минлегирей (1415-1515) во время открытия медресе Зынжырлы произнес такие мудрые слова: «Разум делает человека существом благородным, а путь к совершенствованию разума лежит через науку. Кто не уважает науку, будь он хан или падишах, не сможет создать ничего основательного, ничего, рассчитанного на будущее, и рано или поздно постигает его бесчестье» (Червонная, 1995, c. 127).

\section{Мудрые изречения}

Неисчерпаемый заряд народной мудрости содержит произведения устного народного творчества. К афористическим жанрам фольклора относятся пословицы и поговорки, служившие для сохранения и передачи новым поколениям трудового и житейского опыта. Не случайно тюрко-татары еще называли их «борынгылардан калган сүз» (слово, оставшееся от древних»), «ата-бабалар сүзе» («слово отцов и дедов или предков»).

Пословицы служили своего рода моральным кодексом, были неписаным законом, отражали нормы взаимоотношения людей, эстетические идеалы народа. При несовершенстве официальных законов, слабом проникновении их в сознание широких народных масс (что, судя по записям Ибн Фадлана, еще было характерно для болгарского общества в начале X в.) пословицы играли огромную роль в обществе и были в большом почете. Не зря народная пословица гласила: «Картлар сүзен ишеткәндә, бүркеңне куеныңа куй» («Когда слушаешь слово дедов, возьми шапку под мышку») (Татар халык мәкальләре, 1967, c. 563). Эта пословица, очевидно, бытовала еще у булгар, ибо в ней отражается булгарский обычай держать шапку под мышкой при встрече с почитаемыми, мудрыми людьми (Ибн Фадлан пишет о таком почитании булгар своего царя).

Пословицы и поговорки также являлись украшением разговорного языка, подтверждали и усиливали высказываемую мысль. Немало народных пословиц вошло в литературу, о чем свидетельствуют произведения средневековых тюрко-татарских поэтов и писателей.
Закрепление межгосударственных отношений клятвой или мудрым изречением идет с хуннских времен. Например, в соглашении между государством Хань (206 г. до н. э. 220 г. н. э.) и Домом Хунну имеется примечание: «Небо будет наказывать сторону, нарушившую соглашение, в течение нескольких поколений» (Бичурин, 1950, с. 92).

Булгарские пословицы использовались и в языке дипломатии. Так, например, в 985 г. был заключен мирный договор между Владимиром и булгарами. «И сотвори мир Володимир со болгары, и роте заходиша межю собое. И реша болгаре: «Толи не будет межю нами мира, елико камень начнет плавати, а хмель почнет тонути» (Полное собрание русских летописей, с. 84). Здесь мудрое изречение стало своего рода «печатью», закрепляющее заключенный между государствами договор. Эта пословица существовала и у татар и также использовалась для подкрепления твердости своего слова и дела: «Кайчан кем колмак суга батар, таш суга калкыр, бу вәгъдэ шунда бозылыр» («Когда камень всплывет на поверхность, а хмель станет тонуть, лишь тогда будет нарушено это соглашение») (Татар халык мәкальләре, 1967, с. 780).

Традиция подтверждать договор мудрыми изречениями и клятвами существовала и в Казанском ханстве. На дошедших до нас древнерусских миниатюрах есть сюжеты с изображением сцены клятвы татарских послов в Москве (Арциховский, 1944, с. 129). На них отчетливо видны три атрибута: две или три пары сабель, кубки с каким-то напитком и кусок дерна. Возможно, эти предметы были общими для всех татар, потому что на миниатюрах, изображающих послов из Крыма, видны те же атрибуты. Как бы там ни было, использование именно этих предметов во время заключения клятвенного договора знакомо тюркским народам еще со времен хуннов. Археограф М. Ахметзянов отмечает в своих работах, что выражение «жир кэсе» (дерн) до сих пор сохраняется в татарских поверьях и приметах (Әхмәтжанов, 1992, с. 72-73). Давая клятву землей, говорят: «жир йотсын» (пусть земля проглотит), «жир упсын» (пусть земля разверзнется). Отправляясь в дальний путь, берут с собой горсть родной земли, чтобы вернуться живым и здоровым. Дерн на древних русских миниатюрах, видимо, тоже был привезен послами с родины. Следовательно, эта очень серьезная клятва - клятва самым святым: родной землей, и это - основная часть клятвы. 
Почитание оружия, клятва оружием - также широко распространенное явление с древних времен. Особенно это касается сабель. В древнетюркских источниках сохранилась поговорка: «Пусть она войдет голубой, а выйдет красной». Так говорили, принося клятву на саблях. Махмуд Кашгари так толкует в своем словаре (1072-74-е гг.) смысл этой поговорки: «Когда киргизу, ябаку, кипчаку или любому человеку дают выпить клятвенный напиток, перед ним лицевой стороной кладут саблю и говорят: пусть она войдет голубой, а выйдет красной, то есть обагренной кровью. Если нарушено обещание, то пусть металл тебе отомстит, убьет, покарает тебя» (Кошгари, 1960, с. 342).

Загадки по своему первоначальному назначению и общественной роли примыкают к заклинаниям и табу. В условиях перехода к классовому обществу генетическая роль загадок как средства воздействия на различные явления, предотвращения болезней и т. д., постепенно отошла на второй план, и в них начали усиливаться познавательная и эстетическая функции, роль мудрого изречения.

Загадки становятся формой соревнования в мудрости, находчивости. В прошлом у поволжских татар, как и у их соседей, например, удмуртов, мари, проводились специальные вечера, на которых загадывались и отгадывались загадки. У татар такие вечера проводились в месяце науруз, т.е. в начале года (Татар халык табышмаклары, 1970, с. 32-33). Своеобразные словесные баталии практиковались на царских, ханских приемах, дипломатических встречах, где они становились испытанием мудрости, находчивости и нередко влияли на исход переговоров. Сохранились татарские легенды о булгарских царевнах, которые выбирали себе в женихи того, кто сможет отгадать трудную загадку. Среди них интересна сказказагадка «Сарвиназ», написанная Н. Исанбетом на основе фольклорных источников, и в которой говорится о том, что в Булгаре был объявлен День загадки. Сын хазарского кагана Караногай победил в этом состязании и стал мужем дочери булгарского хана Таймаса (Татар халык табышмаклары, 1970, с. 29, 33, 439-444).

\section{Символы мудрости}

Среди археологических материалов особый интерес представляют предметы с различными изображениями. Раскрытие семантики последних возможно лишь при сопоставлении их с данными фольклора, мифов, литературных образов, материалов языка.

К числу таких предметов следует отнести костяную накладку из билярской коллекции,

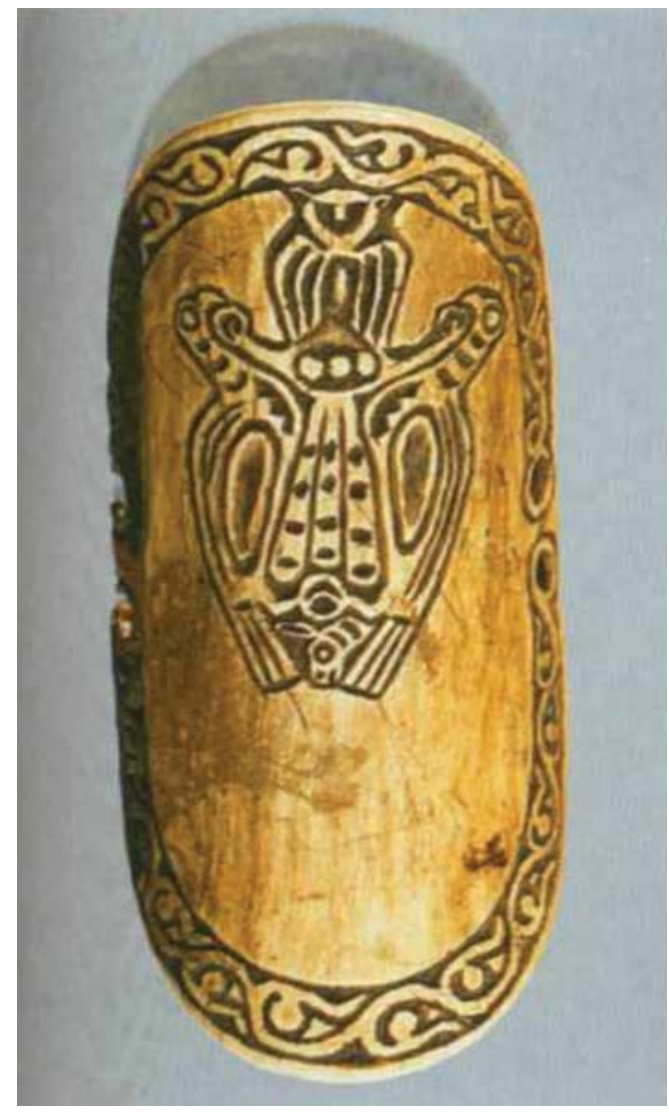

Рис. 1. Пластина на запястье. Кость. XI-XIII вв. Билярское городище и его окрестности. Коллекция А.Ф. Лихачева. Инвентарь № 5427. Национальный музей Республика Татарстан

Fig. 1. The plate on the wrist. Bone. XI-XIII centuries. Bilyar fortified settlement and its surroundings. Collection of A. F. Likhachev. Inventory number 5427. National Museum of the Republic of Tatarstan

служившую для защиты большого пальца (Медведев, 1966, с. 25) от удара тетивы при стрельбе из лука. Вырезанный из полой кости этот предмет имеет форму желоба с закругленными углами. По краям поверхность накладки окружена своеобразным растительным орнаментом. Размеры накладки $10 \times 5$ см, две трети ее плоскости занимает рисунок-изображение филина на голове фантастического зверя (рис. 1). Причем, эта фантастическая голова с ушами, огромными глазами, большим носом составлена из профильного изображения сидящих друг против друга птиц. Между ними три круга или шара. Судя по загнутым клювам и острым когтям, это орлы. Без труда можно различить их оперение, глаза, крылья, хвост. Таким образом, при детальном рассмотрении выясняется, что перед нами изображение филина, сидящего на двух орлах.

Вполне вероятно, что описанный рисунок отражает верования населения Волжской Булгарии домонгольского периода, так как предмет обнаружен в Билярском горо- 
дище, существование которого относится к X-XIII вв. (Халиков, 1973, с. 198-200).

Итак, что можно сказать об этом изображении - о комбинации филина с двумя орлами?

Этимологический анализ тюркских названий филина и совы приводит к аналогичному выводу. Есть мнение, что филин — jabaqulaq состоит из следующих семантических частей: јар - строящий, исполняющий; qu — великий строитель, творец, повелитель; laq - словообразовательный суффикс. Таким образом, тюркское название означает «повелитель», «творец» (Сейидов, 1970, с. 112-114).

По нашему мнению, имя (титул) советника древнетюркских каганов Тонйукука означает «Ночной филин» («Ton - ночь; juquq - филин в древнетюркском языке) (Гумилев, 1993, с. 82). Филин, как в древнегреческой мифологии, у тюрков, позже и у волжских булгар и татар был символом мудрости (Давлетшин, 2004, с. 68).

В татарских народных сказках, народных шутках филин изображается как символ мудрости. Например, в народной сказке «Сын охотника» герой три раза пытается застрелить сову, но филин каждый раз умными речами останавливает его. Филин помогает отыскать таинственный сундук, дает дельные советы, как обычно поступают в татарских сказках мудрые старики и старухи (Татар халык әкиятләре, 1958, с. 82-89).

Отзвук этого мифа мы слышим и в народных шутках. В шутке «Как Ходжа мстил одному баю» говорится о том, как Ходжа проучил одного бая, продав ему филина, который умел произносить одно лишь слово «знаю» (Иркен минем туган илем, 1970, с. 47). И то, что Ходжа Насреддин научил филина произносить именно слово «знаю», указывает на связь данной шутки с древним мифом о мудрости филина.

Широкая распространенность этого мифа среди татарского народа послужила затем причиной того, что филин, как символ мудрости, был часто предоставлен в произведениях средневековой татарской литературы. Так, в стихах поэта Маулэ Кулуй встречаются такие строки о сове (филина) (даются в подстрочном переводе):

Перебирает четки

Слушает дела Судного дня,

Сердце ее в крови (Борынгы татар әдәбияты, 1963, с. 507).

Как известно, мифы не рождаются из ничего. Еще Аристотель назвал мифы лживыми рассказами, сообщающими истину. В появлении исследуемого мифа, возможно, немалую роль сыгра- ли особенные черты этой птицы. Одна из таких черт - крик птицы, похожий на плач человека. В выше приведенных строках из произведений М. Кулуй говорится именно об этой отличительной черте. Филин не зря «плачет», его плач связан с делами Судного дня.

Филин, как символ мудрости, изображается в мифах, сказках и других народов. Изучение их дополняет сюжеты, бытующие у татарского народа, и дает возможность ярче раскрыть смысл данного рисунка.

Например, в казахской сказке «Как байгыз стал птичим бием» (в татарском языке байгыш - другое название совы-филина) рассказывается о том, как филин благодаря своей мудрости, стал царем всех птиц (Казахские сказки, 1964, с. 236-239). В чувашской сказке «Что натворил воробей» говорится о большой птице, похожей на сову, которая выступает в роли судьи (Чувашские сказки, 1971, с. 70-72).

Филина в казахском, татарском и в других тюркских языках называют байгыз/ байгыш/ байгош, означающий как престижная, главная птица (бай кош).

Из-за отсутствия достаточных сведений мы не можем ничего сказать о первоначальном происхождении мифа о филине/сове у того или иного народа, но рассмотренные сюжеты подтверждают ту мысль, что филин, благодаря своей мудрости, является царем всех птиц.

Еще раз обратимся к рисунку на костяной накладке. Филин сидит на двух орлах, которые в мифологии многих народов являются символом силы и могущества. Такое расположение фигур на рисунке дает возможность сказать, что с точки зрения народа мудрость выше даже силы, могущества - орлы склоняются перед мудростью совы, возносят ее как своего царя (бая).

Если ряд животных были связаны с древними тотемистическими традициями, то некоторые представители фауны Среднего Поволжья, Приуралья выступали в роли покровителей определенного промысла, занятий. В этом отношении интересны изображения совы и филина. На бронзовой пломбе из Биляра над изображениями птиц расположен филин (рис. 2). Другое изображение на костяной накладке, предназначенной для защиты большого пальца от удара тетивы - в основном повторяет первый сюжет: филина своими телами поддерживают две хищные птицы, а ниже хвоста филина - отсеченная голова животного (рис. 1). Последняя деталь (пораженное животное) и изображение фили- 


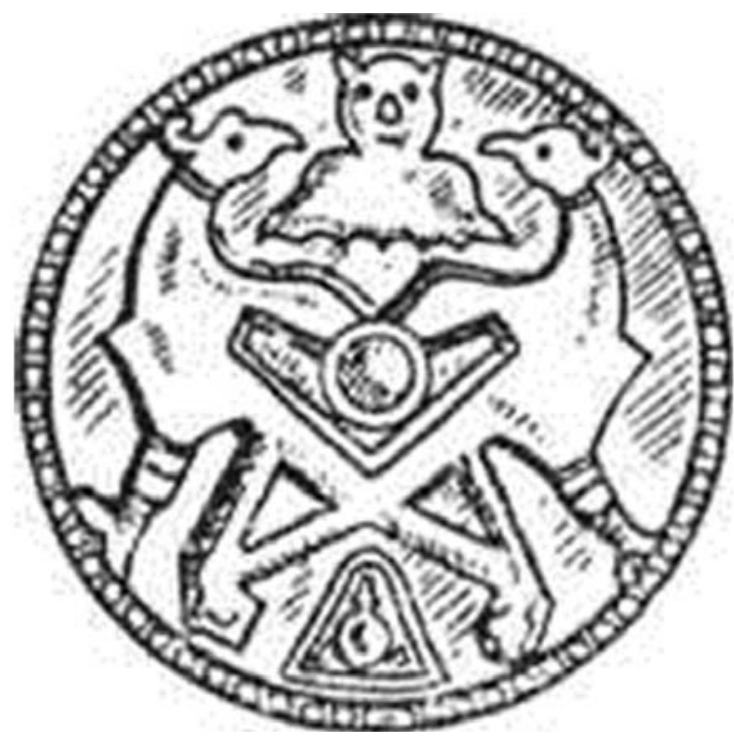

Рис. 2. Бронзовая пломба с изображением филина Fig. 2. Bronze seal with the image of an owl

на на детали лука — главного оружия булгарского охотника, возможно, говорит о филине как о покровителе охотников. Кроме того, важно и расположение филина: он сидит на двух птицах. Две хищные птицы возносят его вверх как своего царя. Действительно, в мифологии и фольклоре филин и сова обычно предстают царями лесных птиц (Татар халык ижаты: Әкиятләр, 1978, с. 108). Судя по фольклорным материалам, царского (престижного) сана он удостоен благодаря своей мудрости. Вспомним древнегреческую богиню войны и победы, а также мудрости, знаний, искусств и ремесел Афину Палладу. Нередко она изображается с совиными глазами или же рядом с ней находится филин (Мифологический словарь, 1991, с. 72).

Стилизованные изображения совы/филина в дальнейшем встречаются в татарском изобразительном искусстве, в частности в орнаментах. По утверждению искусствоведа Ф. Х. Валеева, изображение совы является одним из наиболее распространенных образов в народном искусстве (Валеев, 1969, с. 95).

Итак, миф о филине/сове, как символа мудрости, царя вех птиц, встречаемый в татарском фольклоре, унаследованный с древнетюркского времени, существовал у населения Волжской Булгарии домонгольского времени. Широкое распространение этого образа в современном татарском фольклоре, изобразительном искусстве говорит о тесной связи духовной культуры татарского народа с культурой населения Волжской Булгарии домонгольского периода, уходящая истоками в гуннский и древнетюркские времена.

Тема «Мудрость в представлениях тюркотатар» никем еще специально не изучена. В связи с духовной культурой предков татарского народа некоторые ее историко-культурологические аспекты затронуты Г.М Давлетшиным (Давлетшин, 2004), а в искусствоведческом плане Ф.Х. Валеевым (Валеев, 1969; Валеев, 1975), Д.К. Валеевой (Валеева, 1983; Валеева, 2003).

Однако данная тема в связи обществом, духовным миром тюрко-татар еше комлексно не исследована. Данная статья служит некоторым пополнением этого пробела.

Таким образом, проведенное исследование на основе комплекса источников показывает, что понятие мудрости для тюрко-татар было многоаспектным, мудрость достигалась различными путями (божественный дар, возраст, высокое социальное положение, степень образованности, просвещенности и т.д.). Она имела длительную традицию в духовной жизни тюрко-татар. Мудрость стала синонимом религиозности, просвещенности, грамотности.

\section{Примечание:}

${ }^{1}$ В данной статье предков татарского народа мы условно называем тюрко-татарами. Термин “тюрко-татары”, как обобщенное название всех тюркских народов, вошел в обиход еще в XIX - начале XX вв. Мы под этим термином условно подразумеваем население обширной территории в период от древнетюркского времени до формирования поволжских (казанских) татар.

\section{ЛИТЕРАТУРА}

Арциховский А.В. Древнерусские миниатюры как исторический источник. М.: МГУ, 1944. 213 с. Әхмәтжсқанов М.И. Нәрсә ул “жир кәсе”? (Что такое «жир кэсе»?) // Татарстан. 1992. № 7-8. Б. 72-73. Бичурин Н.Я. [Иакинф]. Собрание сведений о народах, обитавших в Средней Азии в древние времена. Т. І. М.-Л.: АН СССР, 1950. 328 с.

Борынгы татар әдәбияты (Древняя татарская литература). Казан: Таткитнәшр, 1963. 580 с.

Валеев Ф.Х. Орнамент казанских татар. Казань: Таткнигоиздат, 1969. 205 с.

Валеев Ф.X. Древнее и средневековое искусство народов Среднего Поволжья. Йошкар-Ола: Марийск. кн. изд-во,1975. 214 с. 

$240 \mathrm{c}$.

Валеева Д. Искусство волжских булгар периода Золотой Орды (XIII-XV вв.). Казань: Фикер, 2003.

Валеева Д.К. Искусство волжских болгар. Казань: Таткнигоиздат, 1983. 132 с.

Bойтов B.E. Древнетюркский пантеон и модель мироздания в культово-поминальных памятниках Монголии VI-VIII вв. М.: Изд-во Государственного музея Востока, 1996. 152 с.

Гумилев Л.Н. Древние тюрки. М.: Товарищество «Клышников, Комаров и Кํ»,1993. 526 с.

Давлетшин Г.М. Очерки по истории духовной культуры предков татарского народа (истоки, становление и развитие). Казань: Татарское книжное издательство, 2004. 430 с.

Казахские сказки / Сост. и ред. В.М. Сидельников. Алма-Ата: Казах. гос. изд-во художественной литературы, 1964. 430 с.

Кляшторный С.Г. Древнетюркские рунические памятники как источник по истории Средней Азии. М.: Наука. 1964. 215 с.

Ковалевский А.П. Книга Ахмеда Ибн Фадлана о его путешествии на Волгу в 921-922 г. Харьков: Изд-во Харьков. гос. ун-та, 1956. 347 с.

Кошгари М. Девону лугатит турк (Сборник тюркских наречий): В 3-х т.' Ташкент: Фан, 1960. Т. 1.

Малов С.Е. Памятники древнетюркской письменности: тексты и исследования. М.: Изд-во АН CCCP. 1951. $452 \mathrm{c}$.

Мәхмүд әл-Болгари. Нәһжел-фәрадис (Открытый путь к раю) / Әсәрне басмага әзерләүче, кереш мәкалә авторы Фәнүзә Нуриева. Казан: Таткитнәшр, 2002. 384 б.

Мәхмүтов Х.Ш. Борынгылар әйткән сүзләр (VIII-XVII йөз төрки-татар ядкярләрендә афоризмнар) (Слова, сказанные древними (тюрко-татарские афоризмы VIII-XVII вв.). Казан: Фикер. 2002. 255 б.

Медведев А.Ф. Ручное метательное оружие (лук, стрелы, самострел) VIII-XIV вв. / САИ. Вып. E1-36. М.: Наука, 1966. 184 с.

Мифологический словарь / Гл. редактор Е.М. Мелетинский. М.: Советская энциклопедия, 1991. 736 с.

Нинди иркен минем туган илем (Широка моя Родина). Казань, 1970.

Сейидов М.А. Заметки о гуннской мифологии. (VII в.) // Советская тюркология. 1970. № 2. С. 107-116.

ПСРЛ. Т. І. Лаврентьевская летопись и Суздальская летопись по Академическому списку. М.: Вост. лит-ра, $1962.580 \mathrm{c}$.

Татар педагогик фикере антологиясе: ике томда / 1 т. (борынгы төрки чор - XX гасыр башы. (Антология татарской педагогической мысли в двух томах. Том 1. (древний тюркский период - начало ХХ века) / Ф. М. Солтанов (баш мөх.)/ Казан: Татар. кит. нәшр., 2004. 408 б.

Татар халык әкиятләре. Беренче китап (тулыландырылган икенче басмасы) (Татарские народные сказки. Первая книга (дополненное второе издание). Казан, 1958.

Татар халык ижаты: Әкиятләр. Томнарны төзүчеләр, кереш мәкалә һәм искәрмәләрне әзерләүчеләр Гатина X.X., Ярми X.X.: 3 томда (Татарское народное творчество: Сказки / Составители, подготовители вводной статьи и комментарий Гатина Х.Х., Ярми Х.Х. / В 3-х тт. Казан: Таткитнәшр.,1978. 2 т. 447 б.

Татар халык мәкальләре. (Татарские народные пословицы) / Кереш сүз һәм аңлатмалар белән жыючысы һәм төзүчесе Н.Исәнбәт (Соб. и сост. с вводным словом и пояснениями Н. Исанбет). Казан:Таткитнәшр, 1970. 568 б.

Татар халык табышмаклары. (Татарские народные загадки) / Кереш мәкалә һәм аңлатмалар белән жыючысы һәм төзүчесе Н.Исәнбәт (Соб. и сост. с вводным словом и пояснениями Н. Исанбет). Казан: Таткитнәшр, 1970. 568 б.

Халиков А.Х. О столице домонгольской Булгарии // СА. 1973. № 3. С. 82-99.

Червонная С.М. Искусство татарского Крыма. М.: Российская академия Художеств, 1995. 352 с.

Чувашские сказки / Перевод и сост. С. Г. Григорьева; Предисл. В. Б. Микушевича; Ил.: М. Карпенко. М.: Худож. лит.1971. 222 с.

Шерефи X. Зафер наме-и Вилайет-и Казан. Публикация А.Мелек Узйетгин. Предисловие и перевод с турецкого на русский язык Ф.С. Хакимзянова. // Гасырлар авазы=Эхо веков. 1995. Май. С. 83-92.

\section{Информация об авторе:}

Давлетшин Гамирзан Миргазянович, доктор исторических наук, профессор, старший научный сотрудник, Институт языка, литературы и искусства им. Г. Ибрагимова АН РТ (г. Казань, Россия); g.davletshah@mail.ru 


\section{REFERENCES}

Artsikhovskii, A. V. 1944. Drevnerusskie miniatiury kak istoricheskii istochnik (Old Russian Miniatures as a Historical Source). Moscow: Moscow State University (in Russian).

Akhmatzhyanov, M. I. 1992. In Tatarstan. (7-8), 72-73 (in Tatar).

Bichurin, N. Ya. [Iakinf]. 1950. Sobranie svedenii o narodakh, obitavshikh v Srednei Azii v drevnie vremena (Collection of Information about the Peoples who Populated Central Asia in Antiquity) I. Moscow; Leningrad: Academy of Sciences of the USSR (in Russian).

1963. Boryngy Tatars adabiyaty (Ancient Tatar Literature). Kazan: "Tatkitnashr" Publ. (in Tatar).

Valeev, F. Kh. 1969. Ornament kazanskikh tatar (Ornament of Kazan Tatars). Kazan: "Tatknigoizdat" Publ. (in Russian).

Valeev, F. Kh. 1975. Drevnee i srednevekovoe iskusstvo narodov Srednego Povolzh'ia (Ancient and Medieval Art of the Peoples of the Middle Volga Region). Yoshkar-Ola: "Mariiskoe knizhnoe izdatel'stvo" Publ. (in Russian).

Valeeva, D. 2003. Iskusstvo volzhskikh bulgar perioda Zolotoi Ordy (XIII-XV vv.) (Art of the Volga Bolgars of the Golden Horde Period (1 $3^{\text {th }}-15^{\text {th }}$ cc.). Kazan: "Fiker" Publ. (in Russian).

Valeeva, D. K. 1983. Iskusstvo volzhskikh bolgar (Art of the Volga Bolgars). Kazan: "Tatknigoizdat” Publ. (in Russian).

Voitov, V. E. 1996. Drevnetiurkskii panteon i model' mirozdaniia v kul'tovopominal'nykh pamiatnikakh Mongolii VI-VIII vv. (Antient Turkic Panteon and Model of the Universe in Cult and Memorial Monuments of Mongolia of the $6^{\text {th }}-8^{\text {th }}$ Centuries). Moscow: The State Museum of Oriental Art (in Russian).

Gumilev, L. N. 1993. Drevnie Turki (Ancient Turks). Moscow: Tovarishchestvo "Klyshnikov, Komarov and Co." Publ. (in Russian).

Davletshin, G. M. 2004. Ocherki po istorii duhovnoi kul'tury predkov tatarskogo naroda (istoki, stanovlenie i razvitie) (Essays on the History of the Spiritual Culture of the Ancestors of the Tatar People (Origins, Formation and Development). Kazan: Tatar Book Publishing House (in Russian).

Sidelnikov, V. M. (ed.). 1964. Kazakhskie skazki (Kazakh Fairy Tales) Alma-Ata: Kazakh State Publishing House of fiction (in Russian).

Klyashtorny, S. G. 1964. Drevnetiurkskie runicheskie pamiatniki kak istochnik po istorii Srednei Azii (Ancient Turkic Runic Monuments as a Source of Information on the History of Central Asia). Moscow: "Nauka" Publ. (in Russian).

Kovalevskii, A. P. 1956. Kniga Akhmeda Ibn-Fadlana o ego puteshestvii na Volgu v 921-922 gg. (Ibn-Fadlan's Book on His Journey to the Volga in 921-922). Kharkov: Kharkov State University (in Russian).

Koshgari, M. 1960. Devon lugatit turk (Collection of Turkic Dialects) 1. Tashkent: "Fan" Publ. (in Uzbek).

Malov, S. E. 1951. Pamiatniki drevnetyurkskoi pis'mennosti: teksty i issledovaniia (Monuments of Ancient Turkic Writing: Texts and Studies). Moscow: Academy of Sciences of the USSR (in Russian).

Mahmud al-Bulgarian. 2002. Nahel-faradis (An Open Path to Paradise). Kazan: "Tatkitnashr" Publ. (in Tatar).

Makhmutov, Kh. Sh. 2002. Boryngylar aytkan suzlar (VIII-XVIIyoz torki-Tataryadkarlarend aphorismnar) (Words Spoken by the Ancients (Turkic-Tatar Aphorisms of the $8^{\text {th }}-17^{\text {th }} \mathrm{cc}$.). Kazan: "Fiker" Publ. (in Tatar).

Medvedev, A. F. 1966. Ruchnoe metatel'noe oruzhie (luk i strely, samostrel) VIII-XIV vv. (Hand Missile Weapons (Bow and Arrows, Crossbow) of $8^{\text {th }}-14^{\text {th }}$ Centuries). Svod Arkheologicheskikh Istochnikov (Corpus of Archaeological Sources) E1-36. Moscow: "Nauka" Publ. (in Russian).

Meletinsky, E. M. (chief-editor). 1991. Mifologicheskii slovar' (Mythological dictionary). Moscow: "Sovetskaia entsiklopediia" Publ. (in Russian).

1970. Nindi irken minem tugan ilem (My Homeland is Wide). Kazan (in Tatar).

Seyidov, M. A. 1970. In Sovetskaia arkheologiia (Soviet Turkology) (2), 107-116 (in Russian).

Lavrent'evskaia letopis' i Suzdal'skaia letopis' po Akademicheskomu spisku (Laurentian Chronicle and Suzdal Chronicle according to the Academic Code). 1962. Series: Polnoe sobranie russkikh letopisei (Complete Collection of Russian Chronicles) I. Moscow: "Vostochnaia literatura" Publ. (in Russian).

Sultanov, F. M. (chief-ed.). 2004. Tatar pedagogik fikere anthologiyase. 1. Boryngy torki chor-XX gasyr bashy. (Anthology of Tatar Pedagogical Thought. 1. The Ancient Turkic Period - the Beginning of the Twentieth Century). Kazan: "Tatar. kit. nashr." Publ. (in Tatar).

1958. Tatar khalyk akiyatlare. Berenche kitap (tulylandyrylgan ikenche basmasy) (Tatar folk tales. The first book (expanded second edition). Kazan. (in Tatar). 
Gatina, Kh. Kh., Yarmi, Kh.(eds.). 1978. Tatar khalyk and Tatars: Akiyatlar (Tatar Folk Art: Fairy Tales). 2. Kazan: "Tatkitnashr" Publ. (in Tatar).

Isanbet, N. (ed.). 1970. Tatar khalyk makallare (Tatar Folk Proverbs) 3. Kazan: "Tatkitnashr" Publ. (in Tatar).

Isanbet, N. (ed.). 1970. Tatars khalyk tabyshmaklary. (Tatar Folk Riddles). Kazan: "Tatkitnashr" Publ. (in Tatar).

Khalikov, A. Kh. 1973. In Sovetskaia Arkheologiia (Soviet Archaeology) (3), 82-99 (in Russian).

Chervonnaya, S. M. 1995. Iskusstvo tatarskogo Kryma (The Art of the Tatar Crimea). Moscow: Russian Academy of Arts (in Russian).

Grigoriev, S. G. (ed.). 1971. In Chuvashskie skazki (Chuvash Fairy Tales). Moscow: "Khudozhestvennaia literature" Publ. (in Russian).

Sherefi, Kh. 1995. In Ekho vekov = Gasirlar avazı (Echo of Centuries) May, 83-92. (in Russian).

\section{About the Author:}

Davletshin Gamirzan M. Doctor of Historical Sciences, Professor. Institute for Language, Literature and History named after G. Ibragimov, Tatarstan Academy of Sciences, Karm Marx Str., 12, Kazan, 420111, Republic of Tatarstan, Russian Federation; g.davletshah@mail.ru

Статья поступила в журнал 01.04.2021 г. Статья принята к публикации 01.04.2021 г. 